\title{
PENGARUH FAKTOR EKSTERNAL TERHADAP JENIS KAPANG YANG TUMBUH PADA FERMENTASI ARABUSHI
}

\author{
Jamal Basmal") dan Suyuti Nasran*)
}

\begin{abstract}
ABSTRAK
Suatu percobaan pengamatan pengaruh faktor eksternal seperti suhu, tingkat kelembaban, jumlah uap air terhadap jenis-jenis kapang yang tumbuh pada permukaan arabushi selama proses fermentasi alami telah dilakukan. Pengamatan dilakukan di dalam kotak kayu berukuran $28 \times 28 \times 28 \mathrm{~cm}^{3}$. Setiap tutup kotak diberi lubang berdiameter $1 \mathrm{~cm}$. Perlakuan $\mathrm{K} 1$ tidak diberi lubang, perlakuan K2 diberi dua buah lubang, perlakuan K3 diberi tiga buah lubang, dan perlakuan K4 diberi empat buah lubang. Untuk menjaga tingkat kelembaban, seberat $10 \mathrm{~g}$ kapas dibasahi dengan air sebanyak $100 \mathrm{~mL}$ kemudian diletakkan pada dasar kotak percobaan setelah itu ditutup rapat-rapat sehingga udara hanya mengalir melalui lubang. Hasil percobaan menunjukkan bahwa pemberian lubang pada tutup kotak berpengaruh terhadap parameter suhu, tingkat kelembaban udara, dan jumlah uap air di dalam kotak percobaan. Di samping itu jenis kapang yang tumbuh juga menunjukkan perbedaan yang nyata dan diikuti dengan penurunan kadar fenol. Jenis kapang yang tumbuh pada perlakuan K1 adalah Aspergillus chevalieri dengan suhu rata-rata sebesar $27,8^{\circ} \mathrm{C}$ dan $\mathrm{RH}$ rata-rata $67,5 \%$, serta jumlah uap air $13,6 \mathrm{~g} / \mathrm{kg}$ udara kering Pada K2 dan $\mathrm{K} 4$ adalah $A$. flavus dengan suhu rata-rata berturut-turut $28^{\circ} \mathrm{C}$ dan $27,6^{\circ} \mathrm{C}$; persentase RH $83,2 \%$ dan 80,6\%; jumlah uap air 19,3 g/kg udara kering dan 19,6 g/kg udara kering. pada perlakuan $\mathrm{K} 3$ adalah $A$. repens dengan suhu rata-rata $27,8^{\circ} \mathrm{C} ; \mathrm{RH}=76,8 \%$; dan jumlah uap air $18,4 \mathrm{~g} / \mathrm{kg}$ udara kering
\end{abstract}

ABSTRACT: The effect of external factors on the specific mould growing during arabushi (dried stick fish) skipjack tuna (Katsuwonus pelamis) fermentation process. By: Jamal Basmal, Ninoek Indriati, and Nurul Hak.

The effect of temperature, relative humidity and water vapor in the wooden box experiment had been carried-out in special design of wooden boxes to see the specific moulds growing on the surface of arabushi during fermentation. Dimension of wooden boxes was $28 \times 28 \times 28 \mathrm{~cm}^{3}$ with treatments: $K 1$ without hole on the cover, $K 2$ with two holes, $K 3$ with three holes, and K4 with four holes on the middle of the box's cover. The hole diameter was $1 \mathrm{~cm}$. In order to control the humidity in the box, $10 \mathrm{~g}$ of cotton sheets were damped with $100 \mathrm{~mL}$ tap water and were stored on the bottom of the box which was then tighly closed to eliminate air flow inside. Results of experiment showed that variations of total holes influenced the external factors i.e. temperature, relative humidity and water vapor. In addition, it also effected to specific moulds growing on the surface of arabushi. Specific moulds growing on the K1 treatment was Aspergillus chevalieri with $27.8^{\circ} \mathrm{C}$ average temperature, $67.5 \% \mathrm{RH}$, and $13.6 \mathrm{~g} / \mathrm{kg}$ dry air total water vapor. In K2 and $\mathrm{K} 4$ by $\boldsymbol{A}$. flavus grew with $28^{\circ} \mathrm{C}$ and $27.6^{\circ} \mathrm{C}$ average temperature, $83.2 \%$ level of $\mathrm{RH}$, and $80.6 \%$, total water vapor of $19.3 \mathrm{~g} / \mathrm{kg}$ dry air and $19.6 \mathrm{~g} / \mathrm{kg}$ dry air. And in $\mathrm{K} 3$ by $A$. repens with average temperature $27.8^{\circ} \mathrm{C}$, level of RH $76.8 \%$ and total water vapor $18.4 \mathrm{~g} / \mathrm{kg}$ dry air.

KEYWORDS: arabushi, Katsuwonus pelamis, fermentation.

\section{PENDAHULUAN}

Kecepatan pertumbuhan kapang pada permukaan bahan pangan kering sangat tergantung pada faktor fisika, kimia, dan biologi yang yang diperkirakan juga akan memberikan kontribusi besar terhadap jenis kapang yang tumbuh pada permukaan arabushi selama proses fermentasi (Onions et al., 1986). Parameter fisika yang sangat berperan penting adalah suhu, aktivitas air atau tingkat kelembaban, ketersediaan oksigen $\left(\mathrm{O}_{2}\right)$ dan karbon dioksida $\left(\mathrm{CO}_{2}\right)$, nilai $\mathrm{pH}$, dan mungkin juga variasi perbedaan tekanan partial udara, cahaya, dan bentuk-bentuk radiasi lainnya di sekitar produk yang akan difermentasikan Air dan oksigen merupakan faktor absolut yang dibutuhkan selama pertumbuhan kapang. Jenis dan kecepatan pertumbuhan kapang juga dipengaruhi oleh elemen makro seperti karbon, nitrogen, fosfor, potasium, dan magnesium, sedangkan faktor elemen mikro yang dibutuhkan adalah ion-ion besi, seng tembaga, mangan, dan molybdenum (Lilly \& Barnett, 1866). Basmal et al. (1997) menemukan bahwa laju pertumbuhan kapang alami di permukaan arabushi selama proses fermentasi yang dilakukan di dalam

Peneliti pada Balai Penelitian Perikanan Laut 
kotak kayu tertutup rapat sangat lambat. Basmal et al. (1999a) pada penelitian lanjutan dengan melakukan pengontrolan tingkat kelembaban menggunakan humektan $\mathrm{NaCl}, \mathrm{KCL}$, dan $\mathrm{BaCl}_{2}$ jenuh di dalam kotak kaca kedap udara terbukti bahwa penggunaan humektan $\mathrm{NaCl}$ dapat memperlambat pertumbuhan kapang alami pada permukaan produk yang sedang difermentasikan. Sedangkan dengan menggunakan humektan $\mathrm{BaCl}_{2}$ jenuh hanya dalam waktu lima hari, kapang alami telah tumbuh pada permukaan arabushi. Hal ini erat kaitannya dengan tingkat kelembaban di masing-masing humektan yang digunakan, misalnya tingkat kelembaban $\mathrm{BaCl}_{2}$ dalam keadaan jenuh dapat mencapai $89 \%$, sedangkan pada $\mathrm{NaCl}$ jenuh tingkat kelembaban maksimum tercapai hingga 75\%. Northolt et al. (1995) menyatakan bahwa keseimbangan tingkat kelembaban antara produk dan lingkungannya sangat mempengaruhi pertumbuhan kapang, di samping ketersediaan nutrisi produk, suhu, dan oksigen.

Penggunaan kotak kayu sebagai wadah untuk melakukan fermentasi arabushi menjadi katsuobushi telah dikenal baik karena pada permukaan kayu telah tersedia berbagai jenis spora kapang. Di samping itu, kotak kayu mampu mempertahankan dan menyimpan uap air untuk kebutuhan pertumbuhan kapang. Basmal et al. (1999b) menemukan bahwa bila fermentasi dilakukan pada wadah yang kedap air akan terjadi kondensasi pada permukaan dinding wadah dan sebagai akibatnya dapat mengkontaminasi permukaan arabushi. Akibat yang ditimbulkan dengan adanya kondensasi tersebut permukaan produk menjadi sangat lembab dan agak lengket.

Pada proses fermentasi arabushi menjadi katsuobushi tidak semua jenis kapang yang diinginkan tumbuh di permukaan arabusi selama proses fementasi berlangsung, karena dikhawatirkan pertumbuhan kapang yang liar akan menyebabkan terbentuknya mikotoksin selama pertumbuhannya. Menurut Tanikawa (1971), Hanafiah et al. (1987), dan Nasran (1988), jenis-jenis kapang yang diinginkan tumbuh pada permukaan arabushi selama proses fermentasi berlangsung adalah kelompok Aspergillus glaucus, $A$. meleus, dan Penicillium glaucus, sedangkan jenis-jenis kapang yang tidak diinginkan tumbuh antara lain $A$. flavus, A. flavoviridesnes, Torula sp., Cladosporium herbarium, dan Catennlaria fuliginea.

Diduga penggunaan kotak kayu yang diberiventilasi pada tutup kotaknya dapat mempertahankan suhu, tingkat kelembaban, dan jumlah uap air yang sesuai dengan pertumbuhan kapang spesifik ikan kayu seperti $A$. repens dan A. chevalieri.

Tujuan dari penelitian ini adalah untuk mendapatkan jenis dan pertumbuhan optimal kapang, menghindari terjadinya tingkat kelembaban yang tinggi dan untuk memperoleh kualitas katsuobushi yang lebih baik.

\section{BAHAN DAN METODE}

\section{Bahan}

Jenis arabushi yang digunakan pada penelitian ini adalah arabushi cakalang yang telah diolah menggunakan metode yang telah dikembangkan oleh Nasran (1988) yakni ikan disiangi, difilet, direbus, dilakukan kombinasi pengasapan dan pengeringan hingga dicapai kadar air yang diinginkan.

Kotak kayu dibuat dengan ukuran $28 \times 28 \times 28 \mathrm{~cm}^{3}$, terbuat dari jenis kayu meranti, sedangkan untuk mengatur tingkat kelembaban telah ditimbang dan diletakkan di dasar masing-masing kotak sebanyak $10 \mathrm{~g}$ kapas yang telah dibasahi dengan $100 \mathrm{~mL}$ air bersih.

\section{Metode}

Pada dasar kotak kayu diletakkan $10 \mathrm{~g}$ kapas yang telah dibasahi dengan air sebanyak $100 \mathrm{~mL}$ air. Kemudian sebanyak 20 loin arabushi cakalang diatur secara bersilangan di atas rak-rak besi dengan jarak antara kapas basah dengan arabushi $5 \mathrm{~cm}$.

Untuk mengatur tingkat kelembaban, masingmasing kotak percobaan telah dibuat lubang berdiameter satu cm pada tutup kotak. Kotak pertama (K1) tertutup rapat tanpa lubang; kotak ke dua (K2) dibuatkan dua buah lubang; kotak ke tiga (K3) tiga buah lubang; dan kotak ke empat (K4) empat buah. Percobaan dilakukan di dalam ruangan penyimpanan produk dengan dua kali ulangan di Instalasi Penelitian Perikanan Laut Slipi, Jakarta.

Jenis analisis yang dilakukan adalah pengamatan perubahan kadar air menggunakan metode Anonim (1998), nilai $a_{w}$ diukur menggunakan $a_{w}-$ Wert-Messer. Jenis kapang yang dominan tumbuh diidentifikasi menggunakan metode Pitt \& Hocking (1985) dan Samsons et al. (1995). Perubahan suhu dan tingkat kelembaban di masing-masing kotak perlakuan telah dicatat menggunakan pencatat suhu (thermorecorder) yang kemudian diinterpretasikan menggunakan psychometric chart untuk menentukan jumlah uap air yang ada di dalam setiap kotak percobaan.

\section{HASIL. DAN BAHASAN}

Pertumbuhan kapang pada permukaan produkproduk kering tidak hanya dipengaruhi oleh faktor internal (kadar air, nilai $a_{w}$, dan nutrisi produk) tetapi juga dipengaruhi oleh faktor perubahan suhu, tingkat kelembaban, oksigen, dan jumlah uap air udara tempat kapang tumbuh. Pada penelitian ini telah dilakukan 
pengamatan perubahan suhu udara di dalam ruangan fermentasi kotak kayu. Hasil pengamatan selama fermentasi menunjukkan bahwa telah terjadi perubahan suhu dengan kisaran $25,1^{\circ}-33,1^{\circ} \mathrm{C}$. Adanya perbedaan suhu yang relatif cukup tinggi ini mungkin disebabkan oleh aktivitas mikroba di masing-masing kotak percobaan. Diketahui bahwa mikroba atau kapang dalam menguraikan protein, lemak, dan karbohidrat untuk mendapatkan energi akan menimbulkan suatu reaksi panas. Hasil pengamatan perubahan suhu selama proses fermentasi dapat dilihat pada Tabel 1

Pada Tabel 1 dapat dilihat bahwa rata-rata suhu kotak percobaan, kecuali K4 mempunyai rata-rata suhu sama dengan suhu udara (K5), sebaliknya pada perlakuan K1, K2, dan K3 mempunyai suhu yang relatif lebih tinggi daripada $\mathrm{K} 5$. Hal ini cukup beralasan karena energi panas yang diciptakan oleh aktivitas kapang alami yang tumbuh di permukaan arabushi selama fermentasi dapat meningkatkan suhu sekitar ruangan fermentasi. Ternyata dengan memberikan lubang sebagai ventilasi hingga tiga buah lubang dengan diameter masing-masing lubang $1 \mathrm{~cm}$ proses keseimbangan suhunya sedikit terhalang. Pada hasil uji statistik menggunakan persamaan garis linier ditemukan nilai koefisien $\left(r^{2}\right)$ negatif $(-0,7798)$ yang berarti semakin banyak lubang dibuat di permukaan kotak kayu maka proses keseimbangan suhu di dalam kotak dan udara luar akan mudah tercapai. Hal ini cukup beralasan karena secara teoritis dengan semakin sedikit rintangan/pembatas antara suhu di dalam suatu ruangan dengan udara luar, maka udara akan mudah mengalir dari tekanan yang lebih tinggi ke tekanan yang rendah. Hasil pengukuran suhu ratarata ditemukan bahwa proses keseimbangan suhu telah tercapai pada perlakuan K4 dengan suhu udara luar (K5), sedangkan antar perlakuan K1 dan K3 tidak berpengaruh nyata tetapi lebih tinggi dari suhu udara (K5). Pada hasil uji polinomial $\left(X^{6}\right)$ jumlah lubang dengan waktu fermentasi ditemukan koefisien korelasi positif selama proses fermentasi yakni perlakuan $\mathrm{K} 1$ $\left(r^{2}=0,8575\right) ; K 2\left(r^{2}=0,8229\right) ; K 3\left(r^{2}=0,8575\right) ; K 4\left(r^{2}\right.$ $=0,8361)$; dan $\mathrm{K} 5\left(r^{2}=0,6828\right)$. Terlihat pula bahwa pola perubahan suhu antara perlakuan $\mathrm{K} 1$ dan $\mathrm{K} 3$ adalah sama. Pada Gambar 1 dapat dilihat fluktuasi perubahan suhu selama pengamatan.

Pada fluktuasi suhu antara $25,1^{\circ}-33,1^{\circ} \mathrm{C}$, jenis kapang yang tumbuh pada permukaan arabushi lebih didominasi oleh kelompok Aspergillus glaucus yakni pada perlakuan $\mathrm{K} 1$ dengan kisaran suhu antara 25, $1^{\circ}$ $33,1^{\circ} \mathrm{C}$ jenis kapang yang tumbuh adalah Aspergillus chevalieri; K2 dengan kisaran suhu antara $25,6^{\circ}$. $32,8^{\circ} \mathrm{C}$ jenis kapang yang tumbuh adalah $A$. flavus; $\mathrm{K} 3$ dengan kisaran suhu antara $25,1^{\circ}-33,1^{\circ} \mathrm{C}$ kapang yang tumbuh adalah $A$. repens, dan $\mathrm{K} 4$ dengan kisaran suhu antara $25,1^{\circ}-33^{\circ} \mathrm{C}$ jenis kapang yang tumbuh adalah $A$. flavus. Hal ini sesuai dengan penemuan Lilly \& Barnett (1981) yang mengatakan bahwa pada kisaran suhu antara $27^{\circ}-28^{\circ} \mathrm{C}$ permukaan produk kering akan ditumbuhi oleh kelompok A. glaucus.

Adanya fluktuasi suhu di dalam masing-masing kotak percobaan telah menyebabkan terjadinya perubahan persentase tingkat kelembaban $(\mathrm{RH})$. Perubahan tingkat kelembaban di dalam kotak percobaan selain dipengaruhi oleh fluktuasi tingkat kelembaban udara, juga dipengaruhi oleh kecepatan penguapan air pada masing-masing kapas basah yang ada di dalam kotak percobaan. Faktor lain yang menyebabkan terjadinya fluktuasi tingkat kelembaban udara pada masing-masing kotak percobaan tergantung pada aktivitas jasad renik (bakteri dan kapang) alami yang tumbuh pada permukaan arabushi. Diketahui hasil degradasi protein, lemak dan karbohidrat selain menghasilkan energi, polipeptida sederhana tetapi juga akan menghasilkan sejumlah air. Air hasil degradasi nutrisi tersebut dengan adanya perbedaan tekanan udara akan menyebabkan terjadinya difusi uap air dari dalam arabushi ke luar

Tabel 1. Perubahan suhu maksimum, minimum dan rata-rata selama fermentasi alami di dalam kotak kayu

Table 1. Fluctuations of maximum, minimum and average temperature during natural fermentation in wooden boxes.

\begin{tabular}{lccccc}
\hline & \multicolumn{5}{c}{ Suhu (Temperature) $\left({ }^{\circ} \mathrm{C}\right)$} \\
\cline { 2 - 6 } & K1 & K2 & K3 & K4 & K5 \\
\hline Maksimum (Maximum) & 33,1 & 32,8 & 33,1 & 33 & 32,1 \\
Minimum (Minimum) & 25,1 & 25,6 & 25,1 & 25,1 & 25,1 \\
Rata-rata (Average) & 27,8 & 27,7 & 27,8 & 27,6 & 27,6
\end{tabular}

$\mathrm{K} 1=$ kotak tanpa lubang (wooden box without hole); $\mathrm{K} 2$ = kotak dengan dua lubang (wooden box with two holes); $\mathrm{K} 3=$ kotak dengan tiga lubang (wooden box with three holes); $\mathrm{K} 4=$ kotak dengan empat lubang (wooden box with four holes); $\mathrm{K} 5$ = suhu udara (air temperature) 


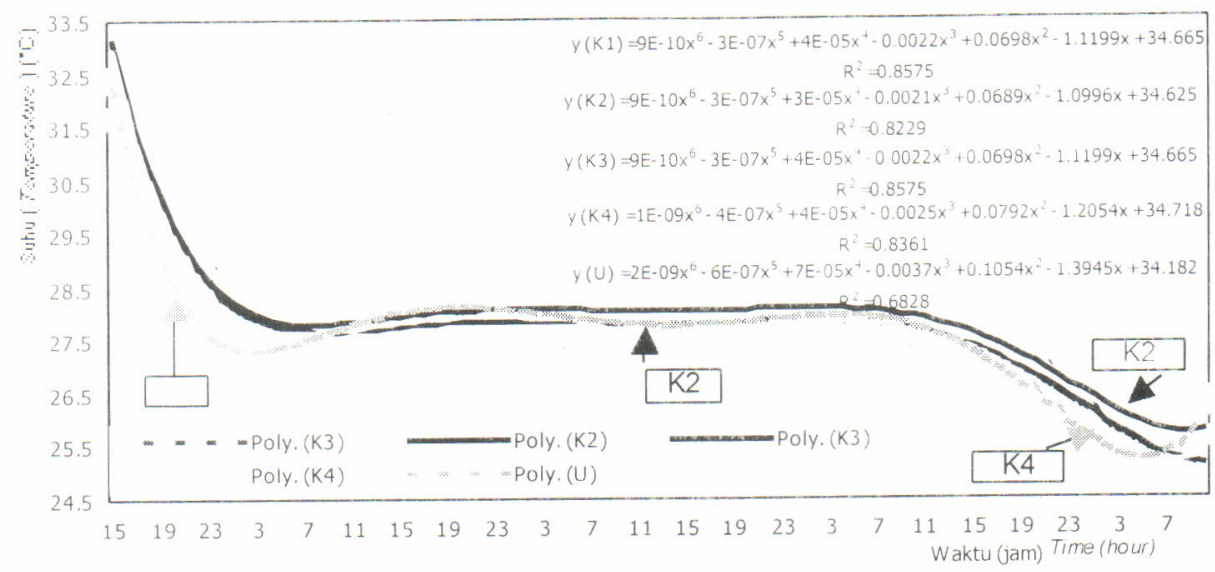

$\mathrm{K}_{1}=$ kotak tanpa lubang (wooden box without hole); $\mathrm{K} 2$ = kotak dengan dua lubang (wooden box with two holes); $\mathrm{K} 3=$ kotak dengan tiga lubang (wooden box with three holes); $\mathrm{K} 4=$ kotak dengan empat lubang (wooden box with four holes); $\mathrm{K} 5=$ suhu udara (air temperature)

Gambar 1. Perubahan suhu dalam kotak kayu selama pengamatan.

Figure 1. Changes of temperature in wooden boxes during the experiment.

sehingga dapat menyebabkan terjadinya perubahan jumlah uap air di masing-masing kotak percobaan. Hanya saja air hasil degradasi nutrisi tersebut lebih sukar menguap dibandingkan dengan air yang ada pada kapas basah. Jika terjadi penguapan uap air dari dalam arabushi akan menyebabkan terganggunya aktivitas kapang sehingga kapang-kapang terseleksi saja yang dapat tumbuh pada permukaan arabushi selama proses fermentasi berlangsung. Sebaliknya bila kecepatan penguapan air yang ada pada kapas basah lebih cepat maka akan menyebabkan terjadinya penyerapan uap air dari udara di dalam kotak percobaan ke permukaan arabushi. Untuk mengurangi terjadinya penguapan dan penyerapan uap air yang berlebihan ke permukaan arabushi selama proses fermentasi, dibuatkan sejumlah lubang pada tutup kotak. Ternyata variasi jumlah lubang telah menyebabkan terjadinya perbedaan tingkat kelembaban (RH). Pada Tabel 2 dapat dilihat bahwa semakin banyak lubang yang diberikan, maka proses keseimbangan/penguapan udara akan semakin meningkat Hasil percobaan terlihat bahwa pada perlakuan K4 tingkat kelembaban udara di dalam kotak lebih tinggi daripada percobaan K1, K2, dan K3. Hasil uji regresi linier variasi jumlah lubang telah menyebabkan terjadinya korelasi yang positif $\left(r^{2}\right)=$ 0,9313 yang berarti bahwa semakin banyak jumlah lubang pada permukaan tutup kotak percobaan, maka proses keseimbangan $\mathrm{RH}$ dengan udara luar akan semakin mudah tercapai.

Ternyata hasil pengukuran rata-rata persentase $\mathrm{RH}$ antar perlakuan berbeda nyata dengan nilai terendah, ditemukan pada perlakuan K1 kemudian diikuti oleh perlakuan K2, K3, dan K4. Adanya perbedaan persentase $\mathrm{RH}$ menyebabkan jenis kapang yang tumbuh berbeda. Hasil identifikasi jenis kapang yang

Tabel 2. Hasil pengukuran maksimum, minimum, dan rata-rata persentase tingkat kelembaban ruangan percobaan.

Table 2. Results of determination of maximum, minimum and average relative air humidity.

\begin{tabular}{lccccc}
\hline \multirow{2}{*}{ Tingkat \% RH (Level of \% RH) } & \multicolumn{5}{c}{ Perlakuan (Treatments) } \\
\cline { 2 - 6 } & K1 & K2 & K3 & K4 & K5 \\
\hline Maksimum (Maximum) & 91 & 89,87 & 83,4 & 92,3 & 96 \\
Minimum (Minimum) & 30,4 & 46,97 & 51,5 & 60,6 & 85,5 \\
Rata-rata (Average) & 67,5 & 75,0 & 76,8 & 80,6 & 94
\end{tabular}

$\mathrm{K} 1=$ kotak tanpa lubang (wooden boxe without hole); K2 = kotak dengan dua lubang (wooden boxe with two holes); $\mathrm{K} 3=$ kotak dengan tiga lubang (wooden box with three hole on cover); $\mathrm{K} 4=\mathrm{kotak}$ dengan empat lubang (wooden box with four hole on top); $\mathrm{K} 5=\mathrm{RH}$ udara (air relative humidity) 
tumbuh pada $\mathrm{K} 1$ adalah $A$. chevalieri; $\mathrm{K} 2=$ A. flavus; $\mathrm{K} 3=A$. repens, dan $\mathrm{K} 4=A$. flavus. Menurut Northolt et al. (1995) persyaratan minimal tumbuh kapang $A$. flavus adalah pada kisaran $a_{w} / \%$ RH $0,78-0,80$, sedangkan untuk $A$. repens antara $0,72-0,74$ dan 0,71-0,73 untuk $A$. chevalieri. Terbukti bahwa peningkatan jumlah lubang pada tutup kotak selain mempengaruhi persentase $\mathrm{RH}$, juga telah mempengaruhi jenis kapang alami yang tumbuh pada permukaan arabushi selama fermentasi tahap pertama. Pada Gambar 2 dapat dilihat perubahan tingkat kelembaban udara pada masing-masing ruangan kotak percobaan selama proses fermentasi.

Hasil uji logaritma masing-masing perlakuan seperti pada Gambar 2 ditemukan nilai (r) mempunyai korelasi positif terhadap waktu yaitu nilai $(r)$ perlakuan K1 adalah 0,8091; $(r)$ pada perlakuan K2 $=0,8927 ;(r)$ pada perlakuan $\mathrm{K} 3=0,8892$; dan $(r)$ perlakuan $\mathrm{K} 4$ sebesar 0,6987 . Antara perlakuan berpengaruh nyata terhadap peningkatan tingkat kelembaban udara yakni dengan meningkatnya jumlah lubang pada permukaan tutup kotak, maka nilai RH kotak semakin mendekati nilai $\mathrm{RH}$ udara (K5), sedangkan dari uji persamaan regresi linier ternyata memberikan nilai ( $r$ ) yang positif $(+0,9940)$. Pada penelitian ini dapat disimpulkan bahwa semakin banyak lubang yang diberikan pada permukaan tutup kotak, maka kontak antara udara di dalam kotak dengan udara luar akan mudah tercapai sehingga keseimbangan udara di dalam kotak dengan udara di luar kotak mudah tercapai. Diketahui bahwa udara luar mengandung berbagai jenis kapang yang mudah mengkontaminasi permukaan arabushiselama proses fermentasi.

Perubahan jumlah uap air di dalam kotak percobaan erat kaitannya dengan perubahan suhu dan tingkat kelembaban udara $(\% \mathrm{RH})$. Apabila suhu bola basah semakin mendekati suhu bola kering, maka jumlah uap air yang terkandung di dalam suatu ruangan tertutup akan semakin mendekati udara jenuh. Untuk mengurangi terjadinya udara jenuh, percobaan telah didesain suatu kotak dengan mengatur aliran udara melalui variasi lubang pada permukaan tutup kotak. Asumsi dengan menvariasikan jumlah lubang pada permukaan tutup kotak adalah untuk mempertahankan tingkat kelembaban sehingga jenis-jenis kapang alami yang diizinkan dapat tumbuh pada permukaan arabushi selama proses fermentasi. Dalam penelitian ini ditemukan bahwa semakin banyak jumlah lubang pada tutup kotak, maka jumlah uap air semakin tinggi seperti pada perlakuan K4 (jumlah lubang pada tutup kotak sebanyak empat buah), jumlah uap air maksimum di dalam kotak sebanyak $23,6 \mathrm{~g} / \mathrm{kg}$ udara kering, sedangkan pada perlakuan $\mathrm{K} 1$ (tanpa lubang pada permukaan tutup kotak), jumlah uap air maksimum di dalam kotak sebanyak 19,2 g/kg udara kering. Sedangkan dari hasil rata-rata perhitungan jumlah uap air di masing-masing kotak percobaan ternyata K4 mempunyai jumlah uap air yang lebih tinggi dibandingkan dengan perlakuan $\mathrm{K} 3, \mathrm{~K} 2$, maupun $\mathrm{K} 1$. Hasil perhitungan menggunakan persamaan garis linier untuk rata-rata jumlah uap air selama percobaan ditemukan persamaan $Y=13,7649+1,5123 X ; r^{2}$

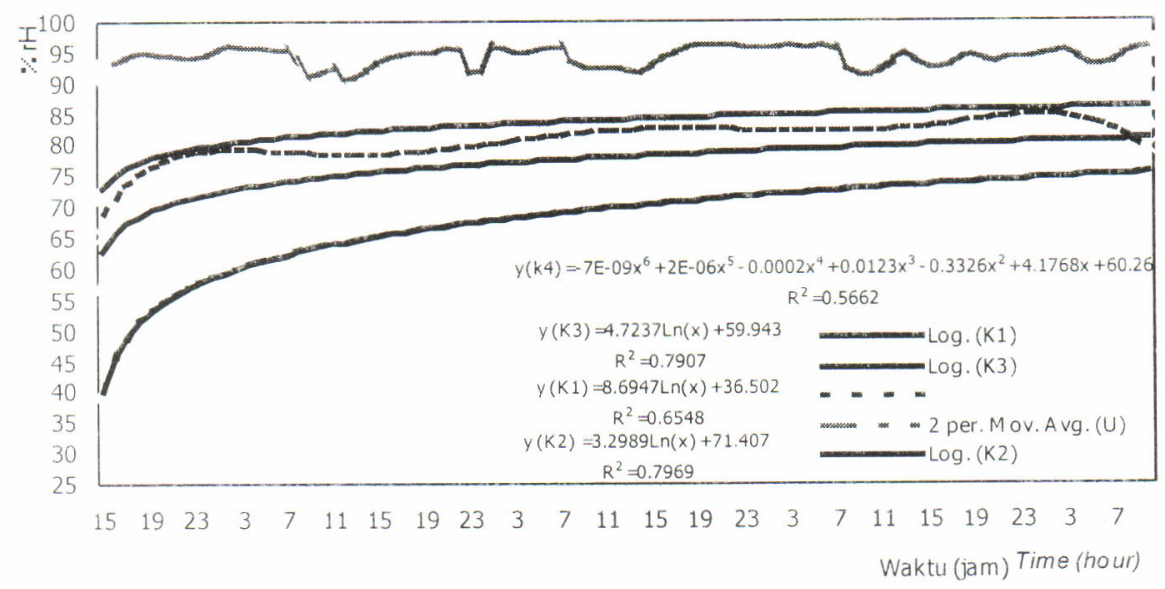

$\mathrm{K} 1=$ kotak tanpa lubang (wooden box without hole); $\mathrm{K} 2$ = kotak dengan dua lubang (wooden box with two holes); $\mathrm{K} 3=$ kotak dengan tiga lubang (wooden box with three holes); $\mathrm{K} 4=$ kotak dengan empat lubang (wooden box with four holes); $\mathrm{K} 5=\mathrm{RH}$ udara (air relative humidity)

Gambar 2. Perubahan tingkat kelembaban ruangan kotak kayu percobaan selama fermentasi tahap pertama arabushicakalang.

Figure 2. Changes of relative humidity in wooden boxes during the first fermentation of dried fish stick (arabushi) skipjack tuna. 
sebesar 0,996. Terbukti bahwa peningkatan jumlah lubang sebagai ventilasi keluar dan masuknya udara ke dalam kotak dapat meningkatkan jumlah uap air di dalam kotak percobaan. Pada Tabel 3 disajikan jumlah uap air di masing-masing kotak percobaan.

Pada Tabel 3 dapat dilihat bahwa pengaruh jumlah lubang udara pada tutup kotak fermentasi telah mempengaruhi jumlah uap air yang ada di dalam ruangan fermentasi. Ruangan fermentasi perlakuan K1 mempunyai jumlah uap air lebih kecil dibandingkan dengan perlakuan lainnya. Hal ini mungkin karena tidak adanya aliran udara dari luar sehingga jumlah uap air yang ada sangat tergantung pada kemampuan menguapkan uap air yang ada pada dasar kotak. Kemungkinan lain rendahnya jumlah uap air pada kotak K1 disebabkan adanya selisih perbedaan tekanan udara di dalam kotak dengan udara luar. Diketahui pula bahwa kayu merupakan penghantar panas yang kurang baik sehingga terjadi akumulasi panas di dalam kotak percobaabn. Sebaliknya pada kotak percobaan yang mempunyai ventilasi (lubang) aliran udara dari dalam maupun ke luar kotak dapat terjadi. Hasil identifikasi jenis-jenis kapang alami yang tumbuh dominan pada permukaan arabushi selama proses fermentasi pada perlakuan $\mathrm{K} 1$ adalah $A$. chevalieri; $\mathrm{K} 2=A$. flavus; $\mathrm{K} 3=A$. repens; dan $\mathrm{K} 4=$ A. flavus. Menurut Pitt \& Hocking (1985) dan Northolt et al. (1995) pertumbuhan kapang sangat dipengaruhi oleh ketersediaan nutrisi, perubahan suhu dan nilai $a_{w} / \%$ RH seperti $A$. flavus mempunyai suhu optimum pertumbuhan pada suhu $25^{\circ}-42^{\circ} \mathrm{C}$ dengan nilai $\mathrm{a}_{w}$ minimal 0,78 pada suhu $33^{\circ} \mathrm{C}$, A. chevalieri mempunyai suhu optimum pertumbuhan pada suhu antara $30^{\circ}$ $35^{\circ} \mathrm{C}$ dengan nilai $a_{w}$ optimum $0,94-0,95 ; A$. repens mempunyai suhu optimum pertumbuhan pada suhu antara $25^{\circ}-27^{\circ} \mathrm{C}$ dengan nilai a optimum 0,95 pada suhu antara $20^{\circ}-25^{\circ} \mathrm{C}$

Variasi jumlah uap air di masing-masing kotak percobaan telah menyebabkan jenis kapang yang tumbuh juga berbeda. Terbukti bahwa kapang $A$ flavus yang tumbuh dominan pada percobaan $\mathrm{K} 2$ dan K4 mempunyai kisaran rata-rata jumlah uap air per kg udara kering antara 17,03 sampai 19,6 g/ $\mathrm{kg}$ udara kering dan ini mungkin merupakan lingkungan yang sesuai untuk pertumbuhannya, sedangkan pada perlakuan K1 rata-rata jumlah uap air per kg udara kering adalah sebesar 13,6 g/kg udara kering dengan jenis kapang yang tumbuh adalah $A$. chevalieri. Pada K3 rata-rata jumlah uap air per kg udara kering adalah sebesar 18,4 g/kg udara kering dengan jenis kapang yang dominan tumbuh adalah $A$. repens. Diketahui bahwa $A$. chevalieri dan $A$. repens adalah jenis kapang yang diinginkan tumbuh pada permukaan arabushi karena di samping dapat menciptakan aroma spesifik katsuobushi, juga tidak memproduksi racun yang dapat membahayakan konsumen selama pertumbuhanya di permukaan arabushi. Menurut Samson et al. (1995) kedua jenis ini tidak memproduksi toksin selama pertumbuhannya Sebaliknya $A$ flavus pada perlakuan K2 dan K4 menurut Troller (1980); Pitt \& Hocking (1980); dan Samsons et al. (1995) dapat memproduksi toksin kojic acid, 3-nitropropionic acid, cyclopiazonic acid, aflkatoksin B1, dan aspergillic acid yang mematikan. Pada Gambar 3 dapat dilihat fiuktuasi jumlah uap air pada masing-masing kotak percobaan

Kecepatan pergerakan uap air di dalam suatu wadah sangat tergantung pada kecepatan aliran udaranya ke udara bebas, suhu, dan kelembaban (Doi, 1998). Hasil pengamatan suhu rata-rata pada masingmasing percobaan menunjukkan perbedaan, kecuali K4 suhu rata-ratanya telah mencapai keseimbangan dengan suhu udara luar. Akibat fluktuasi suhu di dalam kotak telah menyebabkan pula terjadi perbedaan tingkat kelembaban dan jumlah uap air di dalam masing-masing kotak percobaan (Gambar 4).

Persentase RH dan jumlah uap air tertinggi ditemukan pada perlakuan K4 (RH 80,6\%; jumlah uap

Tabel 3. Hasil perhitungan jumlah uap air pada masing masing kotak percobaan

Table 3. Results of computation of water vapour in each of wooden box.

\begin{tabular}{lccccc}
\hline $\begin{array}{c}\text { Jumlah uap air (g/kg udara) } \\
\text { Total of water vapour (g/kg air) }\end{array}$ & \multicolumn{5}{c}{ Perlakuan (Treatments) } \\
\cline { 2 - 6 } & K1 & K2 & K3 & K4 & K5 \\
\hline Maksimum (Maximum) & 19,2 & 21,1 & 20,8 & 23,6 & 27,1 \\
Minimum (Minimum) & 8,4 & 17,7 & 15,9 & 16,8 & 18,9 \\
Rata-rata (Average) & 13,6 & 19,3 & 18,4 & 19,6 & 24,8
\end{tabular}

$K 1=$ kotak tanpa lubang (wooden box without hole); $K 2=$ kotak dengan dua lubang (wooden box with two holes); $\mathrm{K} 3=$ kotak dengan tiga lubang (wooden box with three holes); $\mathrm{K} 4=$ kotak dengan empat lubang (wooden box with four holes); K5 = jumlah uap air di udara (total water vapour of air) 


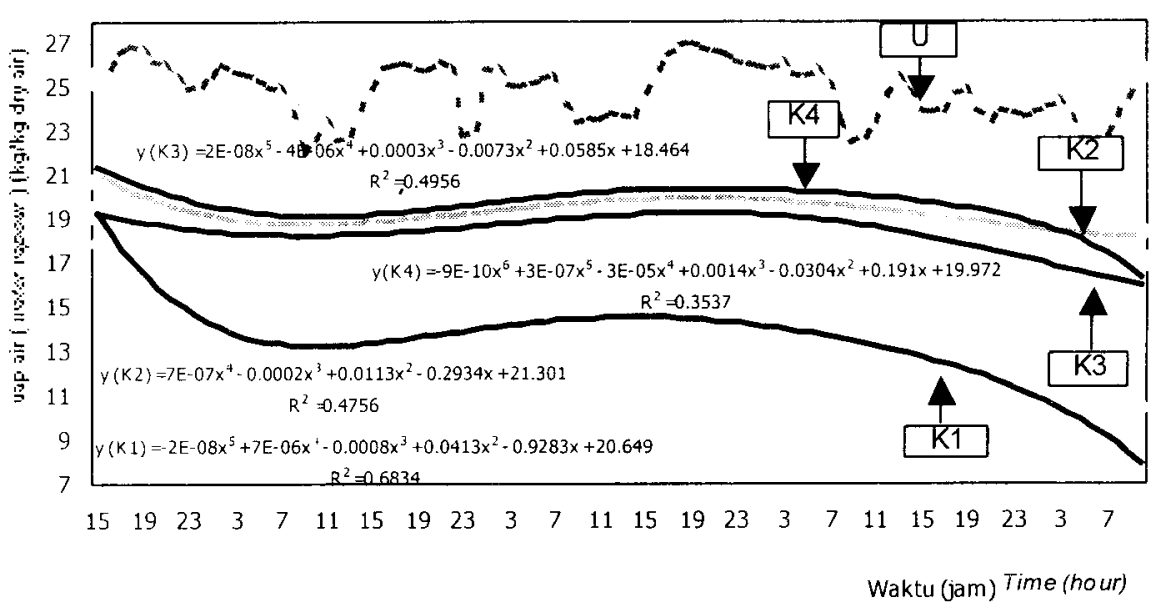

$\mathrm{K} 1=$ kotak tanpa lubang (wooden box without hole); $\mathrm{K} 2=$ kotak dengan dua lubang (wooden box with two holes); $\mathrm{K} 3=$ kotak dengan tiga lubang (wooden box with three holes); $\mathrm{K} 4=$ kotak dengan empat lubang (wooden box with four holes); $\mathrm{K} 5$ = perubahan jumlah uap air di udara (changes of total water vapour in air)

Gambar 3. Perubahan jumlah uap air di dalam kotak kayu percobaan selama fermentasi tahap pertama arabushicakalang.

Figure 3. Changes of total water vapour in wooden boxes during first fermentation of dried fish stick (arabushi) skipjack tuna.

air $19,6 \mathrm{~g} / \mathrm{kg}$ udara kering. Pada kondisi tersebut, Labuza et al. (1972) menyatakan bahwa pada RH lebih besar dari $75 \%$ atau setara dengan lebih besar dari 0,75 nilai $a_{w^{\prime}}$ uap air yang secara bebas ini dapat berfungsi sebagai medium untuk berlangsungnya kerusakan pada produk. Selanjutnya dikatakan oleh Troller (1980) bahwa pada kondisi nilai $\mathrm{a}_{\mathrm{w}} / \% \mathrm{RH}$ antara 0,78-0,80 per $75 \%-80 \%$ adalah merupakan persyaratan minimal tumbuh untuk $A$. flavus dan kapang tersebut dapat menghasilkan toksin pada nilai $a_{w} / \% R H$ minimal $0,83 / 83 \%$. Sebaliknya pada perlakuan $\mathrm{K} 1$ nilai $\mathrm{RH}$ adalah $67,5 \%$, jumlah uap air $13,6 \mathrm{~g} / \mathrm{kg}$ udara kering dan $\mathrm{K} 3$ nilai $\mathrm{RH} 76,8 \%$ dengan jumlah uap air $18,4 \mathrm{~g} / \mathrm{kg}$ udara kering. Kapang $A$. flavus sukar untuk tumbuh pada perlakuan K1 dan K3. Dari hasil identifikasi, jenis kapang yang tumbuh pada perlakuan $\mathrm{K} 1$ adalah $A$. chevalieri dan $\mathrm{K} 3$ adalah $A$. repens. Diketahui bahwa $A$. repens merupakan

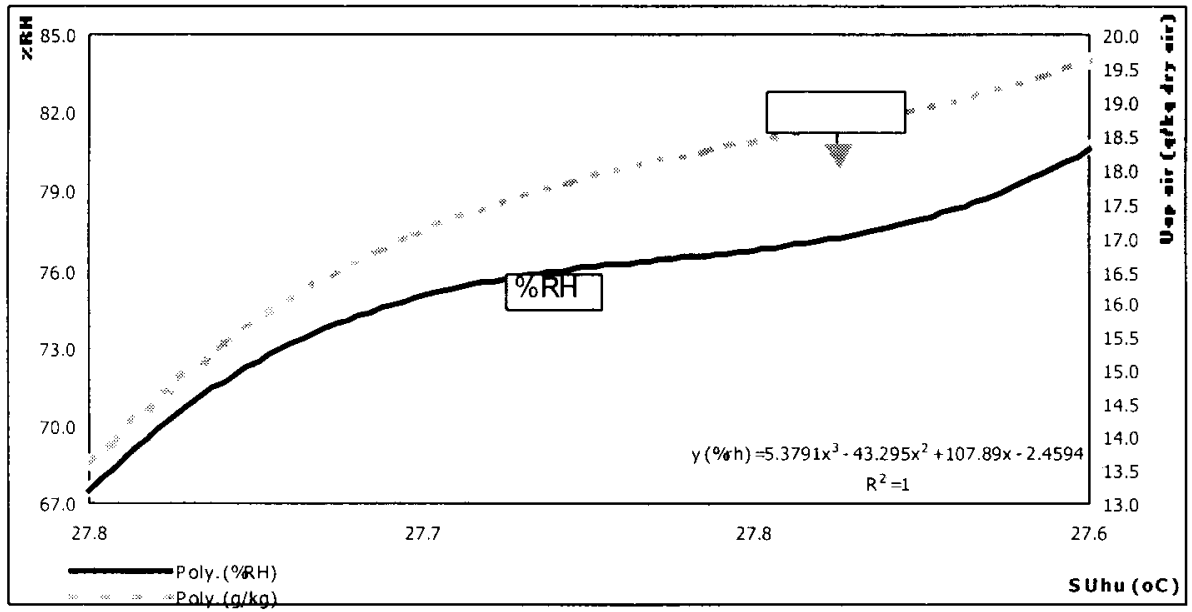

27,8 adalah suhu perlakuan $\mathrm{K} 1$ (27.8 is temperature of $K 1$ treatment); 28,0 adalah suhu $\mathrm{K} 2$ (28.0 temperature of $K 2$ tretament); 27,8 adalah suhu K3 (27,8 is temperature of $K 3$ treatment); and 27,6 adalah suhu K4 (27.6 is temperature of $K 4$ treatment).

Gambar 4. Fluktuasi tingkat kelembaban dan jumlah uap air di dalam ruangan fermentasi.

Figure 4. Fluctuation of absolute relative humidity and water vapour in fermentation cabinet. 
salah satu jenis kapang yang sudah dikenal dalam melakukan fermentasi arabushi menjadi katsuobushi (Doi et al., 1989a dan Samson et al., 1995).

Hasil uji regresi polinomial $\left(X^{3}\right)$ hubungan antar percobaan baik untuk nilai \% RH dan jumlah uap air mempunyai nilai $(r)$ yang positif $\left(R^{2}=1\right)$ yang berarti semakin banyak lubang dibuat pada permukaan tutup wadah fermentasi, maka persinggungan dengan udara luar semakin mudah sehingga titik keseimbangan akan mudah tercapai. Dampak yang ditimbulkan apabila kondisi faktor eksternal ruangan fermentasi tidak dikontrol maka kapang yang tidak diinginkan dapat dengan mudah tumbuh pada permukaan arabushi. Menurut Adnan (1982) pada kondisi RH lebih kecil dari $75 \%$ proses adsorpsi akan mudah terjadi seperti yang terjadi pada perlakuan K2 dan K4. Akibat adanya proses adsorpsi ini permukaan arabushiakan lebih lembab sehingga tidak hanya kapang $A$. flavus saja yang tumbuh tetapi juga kemungkinan akan berkembang biak bakteri pembusuk

Faktor suhu, RH dan jumlah uap air di sekitar arabushi yang sedang difermentasikan ternyata dapat mempengaruhi kadar air dan nilai $a_{w}$ (Gambar 5). Kadar air arabushi sebelum dilakukan fermentasi sebesar 20,44\% (bb = bobot basah) dengan nilai $a_{w}$ sebesar 0,83 . Terbukti setelah fermentasi selama 12 hari kadar air dan nilai a pada percobaan K1 dan K4 lebih tinggi daripada kadar air dan nilai $\mathrm{a}_{\mathrm{w}}$ arabushi, sedangkan perlakuan K2 dan K3 terjadi sedikit penurunan. Jika dihubungkan dengan nilai $\mathrm{RH}$, maka pada perlakuan $\mathrm{K} 1$ telah terjadi proses adsorpsi, sebaliknya pada perlakuan K2, K3, dan K4 terjadi proses absorpsi.
Hasil uji statistik regresi polinomial $\left(X^{3}\right)$ baik fluktuasi kadar air maupun nilai $a_{w}$ mempunyai korelasi positif (Gambar 5) terhadap perubahan jumlah uap air di sekitar ruangan fermentasi. Sedangkan dari hasil analisis nilai a untuk semua perlakuan tidak menunjukkan perbedaan yang nyata. Hal ini cukup beralasan karena analisis nilai $a_{w}$ dilakukan dengan cara memblender satu loin arabushi kemudian diukur nilai $a_{w}-n y a$, sedangkan nilai $a_{w}$ permukaan produk yang merupakan tempat melekatnya kapang di permukaan arabushi selama fermentasi tidak diukur Adanya perbedaan jenis kapang yang tumbuh kemungkinan karena adanya perbedaan nilai a permukaan arabushi dan perbedaan jumlah uap air di masing-masing kotak percobaan. Dampak lain fluktuasi suhu, kelembaban, dan jumlah uap air ruangan fermentasi berpengaruh terhadap fluktuasi kadar air dan nilai a. Setelah dilakukan pengujian secara statistik terhadap hubungan fluktuasi kadar air dan nilai a terdapat persamaan $Y=0,71695+$ $0,0058 X ; R^{2}=0,9281$ yang berarti kadar air dan nilai $a_{w}$ meningkat sesuai dengan perlakuan. Menurut Van Eys \& Mizushi (1983), kapang diperkirakan tidak dapat tumbuh pada kadar air ikan kayu (arabushi) di bawah $20 \%$, selanjutnya Samson et at. (1979) menyatakan bahwa pada kisaran nilai a antara 0,70-0,80 hanya jenis kapang tertentu saja yang dapat tumbuh seperti kelompok Aspergillus spp., dan pada kisaran kadar air antara 14\%-18\% kelompok Penicillium spp. yang akan tumbuh dominan selama proses penyimpanan produk. Adanya variasi perlakuan telah mampu meningkatkan fluktuasi kadar air dan nilai $a_{w}$ arabushi yang sedang difermentasikan sehingga jenis kapang yang tumbuh juga berbeda di setiap perlakuan.

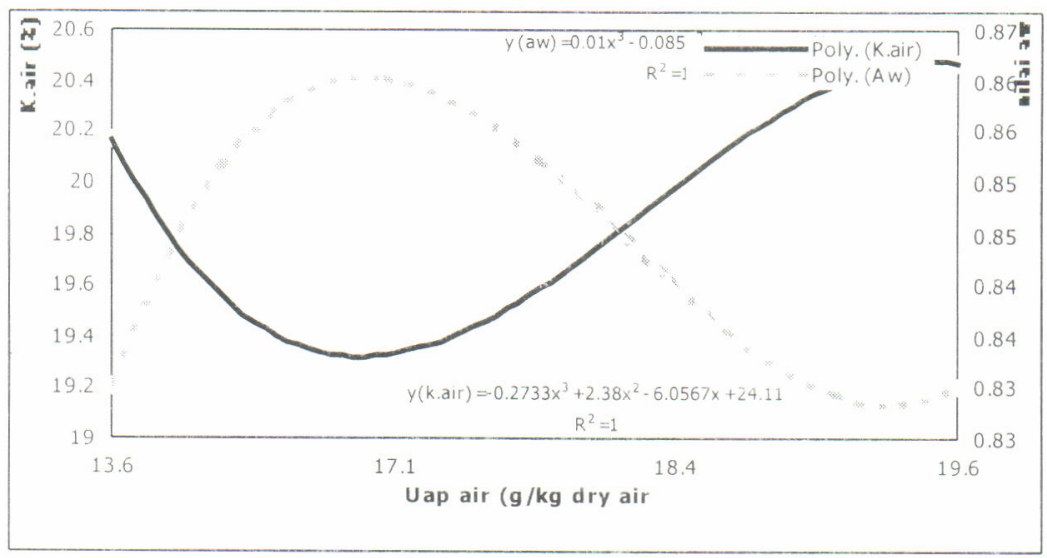

13,6 adalah jumlah uap air di dalam perlakuan K1 (13.6 is total of water vapour in K1 treatment); 19,3 adalah jumlah uap air di dalam perlakuan K2 (19.3 is total of water vapour in K2 treatment); 18,4 adalah jumlah uap air di dalam perlakuan K3 (18.4 is total of water vapour in K3 treatment); 19,6 adalah jumlah uap air di dalam perlakuan K4 (19.6 is total of water vapour in $\mathrm{K} 4$ treatment)

Gambar 5. Hubungan antara kadar air dan nilai $a_{w}$ terhadap jumlah uap air di dalam ruangan fermentasi.

Figure 5. Relation of moisture content and $a_{w}$ value to water vapour in fermentation cabinet. 


\section{KESIMPULAN DAN SARAN}

\section{Kesimpulan}

Variasi jumlah lubang pada permukaan ruangan fermentasi arabushi dapat mempengaruhi faktor eksternal seperti perubahan suhu, kelembaban, dan jumlah uap air di sekitar ruangan fermentasi. Adanya variasi parameter faktor eksternal ini telah mengakibatkan jenis kapang yang dominan tumbuh pada permukaan arabushi selama fermentasi juga berbeda. Pada perlakuan tanpa memberi lubang pada tutup kotak (K1), jenis kapang yang dominan tumbuh adalah $A$. chevalieri; K2 tutup kotak dengan dua lubang jenis kapangya adalah $A$. flavus, K3 tutup kotak dengan tiga lubang jenis kapang adalah $A$. repens, dan K4 tutup kotak dengan empat lubang masing-masing lubang berdiameter $1 \mathrm{~cm}$ jenis kapang yang tumbuh adalah sama dengan perlakuan $\mathrm{K} 2$.

\section{Saran}

Untuk melakukan fermentasi arabushi menjadi katsuobushi perlu dilakukan pengontrolan faktor eksternal seperti suhu, kelembaban, dan jumlah uap air di ruangan fermentasi agar jenis kapang yang diinginkan seperti $A$. repens dan $A$. chevalieri dapat tumbuh dengan baik selama proses fermentasi arabushi.

\section{DAFTAR PUSTAKA}

Adnan, M. 1982. Aktivitas Air dan Kerusakan Bahan Makanan. Penerbit Agritech. Yogyakarta. 28 pp.

Anonim. 1998. Prosedur Analisa Kimiawi Ikan dan Produk Olahan Hasil-hasil Perikanan. Instalasi Penelitian Perikanan Laut Slipi, Jakarta. 100 pp.

Basmal, J., Indriati., N., Nasran, S., dan Hak, N. 1998 Penelitian pendahuluan pengolahan katsuobushi dari ikan cakalang (Katsuwonus pelamis) secara alami. Prosiding Simposium Perikanan Indonesia II. Ujung Pandang 2-3 Desember 1997. Pusat Penelitian dan Pengembangan Perikanan. 377-385.

Basmal, J. dan Nasran, S. 1999a. Pengaruh tingkat kelembaban ruangan fermentasi terhadap pertumbuhan kapang di permukaan ikan kayu (kamebushi) selama proses fermentasi alami. J. Penelitian Perikanan Indonesia. IV(4): 51-57.

Basmal, J. dan Hak, N. 1999b. Fermentasi alami ikan kayu (arabushi) cakalang (Katsuwonus pelamis) dan tongkol (Auxis thazard) dalam eksikator. J. Penelitian Perikanan Indonesia. V(2): 58-67

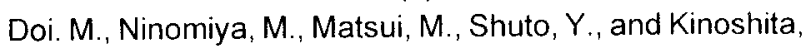
Y. 1989. Degradation and o-methylation of phenols among volatile flavor components dried bonito (Katsuobushi) by Aspergillus species. Journal. Agric. Biol. Chem. 53(4): 1051-1055.

Hanafiah. T.A.R., Winarno, B.I., dan Marasabessy, H. 1987. Proses pembuatan ikan kayu cakalang (Katsuwonus pelamis). J. Penelitian Pascapanen Perikanan. p. 15-22.

Labuza, T.P., Mc Nally, L., Gallagher, D., Hawkes, J., and Hurtado, F. 1972. Stability of intermediate moisture foods. J. Food Sci. 37: 154.

Lilly and Barnett. 1986. Growth requirements and ecology. Smith,s Introduction to Industrial Mycology. Seven edition. By Edward Arnold (Publisher) Ltd. London. p. 271-272.

Nasran, S., 1988. Pengolahan ikan kayu (Katsuobushi). Kumpulan Hasil Penelitian Teknologi Pascapanen Perikanan. p. 45-48.

Onions. A.H.S., Allsopp, D., and Eggins, H.O.W. 1986. Smith's Introduction to Industrial Mycology. Seventh edition. By Edward Arnold (Publisher) Ltd. London. p. 271-283.

Northolt, M.D., Frisvad, J.C., and Samson, R.A. 1995. Occurance of food-borne fungsi and factors for growth. Introduction of Food-borne Fungi. Centraal Bureau voor Schimmel Cultures. Delft. p. 243-250.

Pitt. J.L. and Hocking, A.D. 1985. Fungi and Food Spoilage. Academic Press. Sydney. p. 269-274.

Samsons. R.A., Hoekstra., E.S., Frisvad, J.C., and Filtenborg, O. 1995. Introduction of Food-borne Fungi. Centraalbureau voor schimmelcultures. Delft. p. 240241

Tanikawa, E., Kotohiro, T., and Akiba, M. 1985. Marine Products in Japan. Revised edition. Published by Koseiha Kaseikaku. Co. Ltd. Tokyo. p. 246-252.

Troller. J.A. 1980. Influence of water activity on microorganism in food. Food Tech. 34: 76

Van Eys and Mizushi, P. 1983. Producing fushi for the Japanese markets in FAO. Infofish. Marketing Digest $(3 / 83): 48$ 